УДК 94(470)

DOI 10.37386/2413-4481-2020-4-90-94

\title{
С.Б. Скоробогатов
}

Крымский федеральный университет им. В.И. Вернадского, г. Симферополь, Россия

\section{РОЛЬ АВИАЦИИ ДАЛЬНЕГО ДЕЙСТВИЯ В ПЕРИОД КРЫМСКОЙ ОСВОБОДИТЕЛЬНОЙ ОПЕРАЦИИ 8 АПРЕЛЯ - 12 МАЯ 1944 Г.}

\begin{abstract}
Рассмотрена роль авиации дальнего действия в Крымской наступательной операции. Представлен состав и структура подразделений дальней авиации. Описаны виды боевых задач, примеры героизма личного состава и итоги участия в операции. В работе представлены архивные источники, не опубликованные ранее в научных статьях. В результате исследования установлена роль авиации дальнего действия и личный вклад летчиков бомбардировочных полков в освобождении Крыма от немецко-фашистских захватчиков.

Ключевые слова: авиация, освобождение Крыма, охотник-блокировщик, бомбардировщик, авиационный полк.
\end{abstract}

\author{
S.B. Skorobogatov \\ V.I. Vernadsky Crimean Federal University, Simferopol, Russia
}

\section{ROLE OF LONG RANGE AVIATION DURING THE CRIMEAN LIBERATION OPERATION IN 8 APRIL - 12 MAY 1944}

The article examines the role of long-range aviation in the Crimean offensive operation. The composition and structure of long-range aviation units are presented. The types of combat missions, examples of the heroism of the personnel and the results of participation in the operation are described. The paper presents archival sources not previously published in scientific articles. As a result of the study, the role of long-range aviation and the personal contribution of the pilots of bomber regiments in the liberation of Crimea from the Nazi invaders were established.

Key words: aviation, liberation of Crimea, hunter blocker, bomber, aviation regiment.

Впервые самолеты авиации дальнего действия (далее - АДД) появились в крымском небе во время проведения Новороссийско-Таманской операции, с 9 сентября по 9 октября 1943 года, когда для срыва эвакуации вражеских войск с Кавказа бомбардировкам подвергались крупные транспортные узлы Джанкой и Керчь. Однако наиболее массовое применение АДД в небе Крыма наблюдается в период проведения Крымской наступательной операции, с 8 апреля по 12 мая 1944 г. По замыслу операции для авиационной поддержки наступления 4-го Украинского фронта и Отдельной Приморской армии привлекались 4-я, 8-я воздушные армии и Военно-воздушные силы Черноморского флота. По решению командования, для обеспечения необходимого массированного воздействия на транспортные узлы противника и центр его обороны потребовалось привлечение дополнительных сил - авиации дальнего действия.

Вопросы участия советских бомбардировщиков из авиации дальнего действия в Крымской наступательной операции неоднократно поднимались советскими и российскими исследовате- лями. Наиболее фундаментальными являются работы А.Е. Голованова «Дальняя бомбардировочная» (2004), В.Р. Котельникова «Дальняя авиация» (2004), П.П. Бочкарева «Годы в огненном небе» (1991). Несмотря на значимость этих работ, до сих пор недостаточно изученным остается вопрос о роли авиации дальнего действия в освобождении Крыма в 1944 году. В работе анализировались архивные документы и материалы, не используемые ранее, об участии советских ВВС в наступательной операции Красной Армии в Крыму. Привлечение источников из фондов архивов Российской Федерации позволило углубить научное понимание проблем боевых действий советской авиации в Крыму. Результаты исследования будут востребованы при дальнейшей научной разработке проблем истории Великой Отечественной войны. Материалы проведенного исследования могут быть использованы при создании обобщающих трудов по военной истории России.

На этом основании целью данной статьи является изучение действий и систематизация результатов боевой работы авиации дальнего действия 
в период проведения операции по освобождению Крыма во время Великой Отечественной войны.

Методологией исследования являются принципы научности, объективности, историзма, которые предусматривают политически беспристрастный анализ собранных материалов в контексте конкретной исторической обстановки, использование всех источников и литературы, доступных исследователю. В работе использовались системный, ретроспективный и проблемнохронологический методы.

Авиация дальнего действия представляла собой отдельный род Военно-воздушных сил при Ставке Верховного главнокомандования. В период 1942-1944 гг. командующим АДД являлся генерал-полковник Александр Евгеньевич Голованов.

О роли АДД в Крымской стратегической операции можно судить по сохранившимся журналам боевых действий полков, дивизий и корпусов АДД, отчетам действий фронтов, мемуарам участников боев и другим архивным источникам.

Материальную основу полков АДД составляли самолеты Ил-4 и переоборудованные под бомбардировщики транспортные Ли-2. С июня 1941 г. самолеты Ил-4 являлись основным типом дальних бомбардировщиков, производившихся в Советском Союзе. Свой вклад в освобождение Крыма внесли 3-й, 5-й, 8-й, 9-й, 10-й, 18-й, 19-й, 20-й, 21-й и 24-й гвардейские АП, вооруженные Ил-4 [1, с. 122]. Всего 10 полков АДД.

Ил-4 (до 1942 г. назывался ДБ-3Ф) - двухмоторный цельнометаллический моноплан с убирающимся шасси. С 1937 по 1945 гг. было выпущено 6785 экземпляров. Максимальная скорость составляла 445 км/ч, потолок полета 9700 м, дальность 4200 км. Вооружение включало бомбовую нагрузку до 2000 кг, стрелковое вооружение 2х7,62 мм и 1х12,7 мм пулеметов [2].

Кроме того, еще в 4 полках АДД применялись американские бомбардировщики Б-25 «Митчелл», поступавшие в СССР по ленд-лизу. Самолетами Б-25, модификаций С, D и J, были вооружены 13-й, 14-й, 15-й, 22-й, гвардейские АП. Из 5815 построенных в США самолетов в СССР было поставлено 862 машины. Максимальная скорость самолета Б-25С - 450 км/ч, дальность 2420 км, потолок 6460 м. Вооружение включало бомбовую нагрузку до 1360 кг, 6х12,7 мм пулеметов.

Самолет В-25, модификации J, выпускался в США в соответствии с требованиями советской авиации. Его максимальная скорость составляла 444 км/ч, дальность - 2170 км, потолок 7470 м. Вооружение включало 8х12,7 мм пулеметов, бомбовая нагрузка - 1814 кг [3].
Американские бомбардировщики А-20-Ж «Бостон», также поступавшие в СССР по лендлизу, использовались в 26-м и 27-м гвардейских АП ночных охотников-блокировщиков (НОБ) в качестве ударных машин для штурмовки наземных объектов с января 1944 г. [4, с. 182]. Для дальних полетов в бомбовом отсеке устанавливали дополнительные бензобаки. Максимальная скорость самолета А-20Ж - 510 км/ч, дальность 1610 км, потолок 7200 м. Вооружение самолета модификаций А-20-Ж составляло четыре 20-мм пушки и два 12,7-мм пулемета в носу самолета и два пулемета для обороны в хвостовой части.

Непосредственно при освобождении территории Крыма в апреле-мае 1944 г. в боях принимали участие четырнадцать гвардейских бомбардировочных полков (гв. АП), собранных в шесть гвардейских авиационных дивизий (гв. АД) из 2-го, 3-го и 4-го гвардейских авиационных корпусов (гв. АК), 50-й авиационной дивизии (АД) 6-го авиационного корпуса (АК) АДД [5, с. 85].

Основными задачами АДД в апреле-мае 1944 г. являлись:

- разрушение транспортных узлов и срыв железнодорожных перевозок на западном направлении;

- уничтожение узлов обороны и содействие наземным войскам в успешном наступлении;

- срыв эвакуации и ликвидация обороны немецких войск на Крымском полуострове в районе г. Севастополя.

На первом этапе Крымской наступательной операции АДД наносила удары по крупным транспортным узлам в Румынии с целью недопущения подвоза немецко-румынских войск и техники, а также организованной эвакуации из Крыма морским путем. С этой целью АДД взаимодействовала с кораблями Черноморского флота и его Военно-воздушными силами.

В дальнейшем бомбардировщики АДД наносили удары по тылам вражеских войск, артиллерийским батареям и оборонительным сооружениям в районе г. Севастополя совместно с фронтовой авиацией [6].

Экипажи выполняли налеты по ночам. Тактика применения АДД предусматривала предварительную отправку самолета «разведчика погоды». По результатам его доклада принималось решение о возможности вылета основной группы. Задачей первого звена - «лидеров» бомбардировщиков - обнаружить цель и обозначить ее световыми авиационными бомбами (САБ). Самолеты «ночных охотников-блокировщиков» атаковали ближайшие к маршруту аэродромы противника с 
целью недопущения вражеской воздушной атаки во время налета, а также атаковали позиции зенитных прожекторов и артиллерии. Замыкающими шли экипажи «контролеров», которые производили визуальную оценку и фотографирование объекта после удара [7, с. 13].

Так, вначале операции бомбовые удары по румынским портам Констанца и Галац силами всех четырех АК АДД способствовали срыву организации и подвоза подкреплений для германской 17-й армии в Крым. Также с 15 апреля скоординированные удары наносились по порту Севастополя для срыва эвакуации войск из Крыма. Удары по переднему краю обороны противника наносились в ночь на 4 мая, в преддверии отвлекающего удара 2-й гв. армии на северо-востоке г. Севастополя.

В дальнейшем с 6 по 8 мая удары наносились на юго-востоке от г. Севастополя. Их целью было содействие наступлению советских наземных войск 51-й армии и Приморской армии перед основным штурмом Сапун-горы, а также для развития наступления на г. Севастополь. После взятия рубежа Сапун-горы, с 9 по 11 мая, АДД действовала по бухтам г. Севастополя, способствуя срыву эвакуации немецко-румынских войск из Крыма.

Рассмотрим результаты боевых действий каждого из авиационных корпусов АДД и роль составляющих их подразделений в операции по освобождению Крыма в апреле-мае 1944 г.

В составе 2-го гв. АК АДД в Крымской наступательной операции участвовали две дивизии: 2-я гв. АД, состоящая из 3-го, 18-го гв. АП и 26-го гв. АП ночных охотников-блокировщиков, и 8-я гв. АД, состоящая из 8-го и 19-го гв. АП. В рассматриваемый период полки 2-го гв. корпуса базировались в г. Прилуки Черниговской области.

В апреле 2-й гв. АК дважды наносил удары по порту Констанца и один раз по порту Галац, а также четыре раза наносил удары по Севастополю. В ночь на 4 мая 1944 г. 2-я гв. АД действовала по скоплению живой силы и артиллерийским позициям противника в районе Севастополя. Цель бомбардировалась 39 самолетами с высоты 1 800-2 100 м. Всего было сброшено 47445 кг бомб [8, л. 5].

Блокирование средств противовоздушной обороны (ПВО) в районе цели и аэродрома Херсонес осуществляли 9 самолетов-блокировщиков А-20-Ж из 26-го гв. АП. Освещение цели было организовано на высоком уровне, 3 самолета сбрасывали световые авиационные бомбы с интервалом в 5 минут, обеспечивая одновременное горение до 15 осветительных бомб над целью. Результатом налета являлся большой пожар площадью 200-300 м² и 3 взрыва большой силы. Самоле- ты А-20-Ж уничтожили 3 зенитных прожектора и подавили огонь по одной артиллерийской, минометной и малокалиберной батарее. По оценке штаба дивизии, удар был произведен с большой организованностью и тактической грамотностью. Потерь со стороны советской авиации не было [9, л. 31].

Таким образом, в Крымской наступательной операции в период с 8 апреля по 12 мая 1944 г. экипажами 2-го гв. АК было выполнено $690 \mathrm{ca}-$ молетовылетов, из них по Севастополю - 508. На врага было сброшено 150,508 т бомбовой нагрузки в Румынии и 446,520 т в Крыму [10, с. 188].

3-й гв. АК АДД был представлен двумя дивизиями: 3-й гв. АД в составе 10-го и 20-го гв. АП и 7-й гв. АД в составе 9-го и 21-го гв. АП. В рассматриваемый период полки 3-го гв. корпуса базировались в г. Белая Церковь и аэродроме Жуляны под Киевом.

Экипажи 3-го гв. АК АДД в апреле 1944 г. нанесли два бомбовых удара по румынскому порту Констанца и один - по порту Галац. По Севастополю в апреле-мае было нанесено девять бомбовых ударов. Одним из ярких представителей героев авиации дальнего действия, освобождавших Крым, был дважды герой Советского Союза В.В. Сенько. Так, 7 и 8 мая 1944 года Сенько участвовал в качестве штурмана лидирующего экипажа 10-го гвардейского авиаполка в налетах на г. Севастополь [2, с. 159].

Итогом участия 3-го гв. АК АДД в Крымской наступательной операции в период с 8 апреля по 12 мая 1944 г. стали 186 самолетовылетов по Румынии и 503 по Севастополю. На врага было сброшено 189,240 т бомбовой нагрузки в Румынии и 488,010 т в Крыму [11].

В состав 4-й гв. АК АДД также входили две дивизии: 4-я гв. АД, состоящая из 13-го, 15-го гв. АП и 27-го гв. АП НОБ, и 5-я гв. АД в составе 14-го и 22-го гв. АП. В рассматриваемый период корпус базировался в г. Конотоп Сумской области.

Существенное влияние на результаты бомбовых ударов самолетов 4-го гв. АК АДД оказало состояние летного поля в местах базирования. В условиях весенней распутицы апреля 1944 г. далеко не все экипажи были способны выполнить взлет и посадку с расчетной бомбовой нагрузкой. Установление хорошей погоды в мае способствовало высыханию грязи и затвердеванию покрытия летного поля, что сказалось на увеличении средней бомбовой нагрузки на один самолет с 1175 кг до 1450 кг и позволило привлекать к боевой работе большее количество экипажей, обладавших меньшим опытом. 
По данным отчетных документов, 4-й гв. АД, 27-й гв. АП ночных охотников-блокировщиков в мае 1944 г. совершили 44 вылета по блокированию аэродромов и ПВО в районе г. Севастополь, а также атакам кораблей в бухте Казачья. При бомбардировке бухты восемь бомбардировщиков были пойманы в лучи прожекторов, один самолет-фотограф имел повреждения от осколков снарядов [12, л. 25].

В качестве характеристик цели указывалось, что по ночам авиационного противодействия в районе Констанца нет. Огонь румынских ПВО имел заградительный характер, был не очень интенсивным и прицельным. А в налете на город и порт Галац в одной из атак стрелки советских бомбардировщиков сбили вражеский истребитель. В то же время наиболее сильная ПВО отмечалась в налетах на порт Севастополь.

Таким образом, экипажами 4-го АК в апреле и мае 1944 г. на разрушение морских и речных портов Констанца, Галац, Севастополя было выполнено 487 самолетовылета. На противника в Румынии было сброшено 145,220 т, а в Севастополе - 447,095 т [13].

Еще одним корпусом, принимавшим участие в операции по освобождению Крыма, являлся 6-й авиационный корпус (АК) АДД. В боевых действиях на территории Крыма принимала участие только одна дивизия корпуса - 50-я АД ДД в составе 5-го гв. АП и 24-го гв. АП. По состоянию на начало марта 1944 г. самолеты дивизии базировались на аэродроме Станиславчик и Ротмистровка в Черкасской области.

В апреле 1944 г. боевые действия частей 50-й АД определялись наступательными операциями 2-го и 3-го Украинского фронта на Львовском, Кишиневском и Одесском направлениях, а также действиями 4-го Украинского фронта, направленными на освобождение Крыма. В апреле на Крым состоялось семь боевых вылетов в составе дивизии, а в мае - четыре. На разрушение морских и речных портов противника в Румынии было выполнено 74 самолетовылета, по Севастополю 214. На врага в Румынии сброшено 75,525 т, а в Крыму - 214,293 т [14, л. 1].

В боях за освобождение Крыма участвовали экипажи дважды Героя Советского Союза, заместителя командира эскадрильи 5-го гв. АП гвардии капитана В.Н. Осипова, в котором помимо командира звание Героя Советского Союза было присвоено штурману корабля Б.П. Гущину и стрелку-радисту В.И. Синицыну. В этом же полку над Крымом сражались дважды Герой Советского Союза, командир эскадрильи майор П.А. Таран и штурман его экипажа А.П. Карпенко, также ставший Героем Советского Союза. Командир эскадрильи 24-го гв. АП гвардии капитан С.И. Кретов сражался над Крымом в звании Героя Советского Союза, а свою вторую медаль «Золотая звезда» получил после Великой Отечественной войны.

Таким образом, всего в операции по освобождению Крыма самолеты АДД выполнили $1984 \mathrm{ca}-$ молетовылетов, сбросив 43565 бомб весом $1491 \mathrm{t}$, 378 самолетовылетов выполнено в ходе ударов по портам Румынии. Общие итоги боевой деятельности авиации дальнего действия в период Крымской освободительной операции в период с 8 апреля по 12 мая отражены в таблице.

Вместе с тем следует отметить проблемы со стороны тылового обеспечения, приводившие к простаиванию самолетов:

- нехватка запасных частей, в основном к самолетам иностранного производства;

- плохое качество покрытия взлетно-посадочных полос, раскисший грунт, влиявшие на снижение объема боевой нагрузки на самолет.

Кроме того, плохие метеорологические условия в районах полета и цели также снижали количество боевых вылетов и качество бомбометания, а также не всегда позволяли объективно оценить результаты атак.

Итоги боевой работы авиации дальнего действия в Крымской операции (апрель-май 1944 г.)

\begin{tabular}{|c|c|c|}
\hline АК и АД & Количество самолетовылетов & $\begin{array}{c}\text { Масса сброшенного боевого запаса } \\
\text { (в тоннах) }\end{array}$ \\
\hline 2 -й гв. АК & 690 & 597028 \\
\hline 3 -й гв. АК & 689 & 637250 \\
\hline 4 -й гв. АК & 487 & 592315 \\
\hline 50 -я АД (6-й АК) & 288 & 289818 \\
\hline Общий итог & 2154 & 2116411 \\
\hline
\end{tabular}


Всем полкам АДД, участвовавшим в освобождении Севастополя, была объявлена благодарность в приказе ВГК № 111 от 10 мая 1944 г. [15, с. 216].

По результатам боевой деятельности АДД в Крымской операции приказом НКО № 0137 от 27 мая 1944 года частям и соединениям 2-го гв. АК - 18-му гв. АП и 2-й гв. АД были присвоены почетные наименования "Севастопольских». 3-й гв. АП был награжден орденом Красного Знамени. Результатом боевой деятельности 3-го гв. АК стало присвоение 20 -му гв. АП и 7-й гв. АД почетных наименований - «Севастопольских». По результатам боевой деятельности 4-го гв. АК 15-му и 22-му гв. АП были присвоены почетные наименования «Севастопольских». 5-й и 24-й гв. АП из 6-го АК получили почетные наименования «Севастопольских», а 50-я АП дальнего действия стала «Крымской».

Таким образом, в результате бомбовых налетов на румынские порты Галац и Констанца в апреле 1944 г. противнику был нанесен материальный ущерб, сказавшийся на интенсивности эвакуации войск из Крыма. Удары по Севастополю способ- ствовали прорыву обороны противника и успешному штурму Сапун-горы, разрушению инфраструктуры аэродромов, порта и противовоздушной обороны города. Использование экипажей лидеров, самолетов-осветителей и тщательная подготовка к боевому заданию способствовали успешному выполнению боевой задачи. С поставленными задачами все полки авиации дальнего действия справились, что подтверждается выполнением контрольных фотоснимков и рапортами контролирующих офицеров.

В операции по освобождению Крыма участвовали четыре летчика дважды Герои Советского Союза: В.Н. Осипов, П.А. Таран, В.В. Сенько, Е.П. Федоров и более двадцати летчиков, уже являвшихся на тот момент или ставших впоследствии Героями Советского Союза.

Таким образом, части и соединения авиации дальнего действия внесли весомый вклад в разгром немецко-румынских оккупантов в Крыму, что наряду с действиями других видов и родов авиации предопределило победу в Крымской наступательной операции.

\section{Библиографический список}

1. Голованов А. Е. Дальняя бомбардировочная. М.: ООО «Дельта НБ», 2004. 436 с.

2. Котельников В., Раткин В., Золотов В., Михеев В. Дальняя авиация. Первые 90 лет. М.: Полигон-пресс, 2004. 370 c.

3. Котельников В. Р. Авиационный ленд-лиз. М.: Фонд «Русские Витязи», 2015. 368 с.

4. Бочкарев П. П., Парыгин Н. И. Годы в огненном небе (Авиация дальнего действия в Великой Отечественной войне 1941-1945 гг.). М.: Воениздат, 1991. 320 с.

5. Ткаченко С. Н. Авиация дальнего действия в Крымской наступательной операции (апрель - май 1944 г.) // Актуальные вопросы истории, историографии и источниковедения Юга России: к 75-летию освобождения Крыма от немецко-фашистских захватчиков: материалы региональной научно-практической конференции, Симферополь, 7 мая 2019 г. Симферополь: ИТ «АРИАЛ», 2019. 100 с. 896 c.

6. Исаев А. В., Хазанов Д. Б., Романько О. В., Глухарев Н. Н. Битва за Крым 1941-1944 гг. М.: Эксмо, 2017.

7. Попов Н. 4-й Гвардейский авиационный корпус дальнего действия в Великой Отечественной войне // Авиационный журнал. 1993. № 2-3.

8. Ц Центральный архив Министерства обороны Российской Федерации (ЦА МО РФ). Ф. 20505. Оп. 1. Д. 16.

9. ЦА МО РФ. Ф. 20016. Оп. 1. Д. 0025.

10. Киньдюшев И. И. К победным рассветам. М.: Воениздат, 1978. 246 с.

11. ЦА МО РФ. Ф. 20562. Оп. 1. Д. 15.

12. ЦА МО РФ. Ф. 20061. Оп. 1. Д. 0016.

13. ЦА МО РФ. Ф. 20516. Оп. 1. Д. 23.

14. ЦА МО РФ. Ф. 20114. Оп. 1. Д. 142.

15. Освобождение городов: справочник по освобождению городов в период Великой Отечественной войны 1941-1945 / М. Л. Дударенко, Ю. Г. Перечнев и др. М.: Воениздат, 1985. 598 с. 